\title{
INTERACTIONS OF RHEUMATOID FACTOR WITH IMMUNE PRECIPITATE CONTAINING ANTIBODY OF HUMAN ORIGIN
}

\author{
BY \\ MORTEN HARBOE \\ Institute for Thrombosis Research, University Hospital (Rikshospitalet), Oslo, Norway
}

The term "rheumatoid factor" is applied to the macroglobulin component of serum which is responsible for a group of serological reactions used as diagnostic procedures in rheumatoid arthritis.

The rheumatoid factor is able to react with antigen-antibody complexes of diverse origins. It agglutinates sheep red cells sensitized with rabbit amboceptor (Waaler, 1940; Rose, Ragan, Pearce, and Lipman, 1948), Rh-positive red cells coated with selected incomplete anti-D antibodies of human origin (Foz and Batalla, 1956; Grubb, 1956; Waller and Vaughan, 1956), and Brucella abortus sensitized with a strong incomplete anti-Brucella antibody of human origin (Foz and Batalla, 1956).

Rheumatoid factor is adsorbed on to immune precipitates consisting of various antigens and the corresponding rabbit antibodies (Vaughan, 1956; Edelman, Kunkel, and Franklin, 1958; Vaughan, Ellis, and Marshall, 1958; Corcos, 1960; Mellors, Nowoslawski, Korngold, and Sengson, 1961). Vaughan (1956) observed that absorption with an immune precipitate consisting of diphtheria toxin and human antitoxin did not reduce the activity of one rheumatoid serum in the Waaler-Rose test. Under the experimental conditions, a considerable solubility of the precipitate made the quantitative data uninterpretable. Additional data were not available in the literature concerning reactions of rheumatoid sera with immune precipitates containing antibody of human origin.

Recently, we have had the opportunity of studying a strong human precipitin and its reactions with rheumatoid sera. The present paper describes the results of these experiments. After completion of the experiments, we learned of the independent investigations of Aho, Kirpilä, Wager, and Virkkunen (1961) which confirm and extend our findings.

\section{Materials and Methods}

Precipitating Antibody.-The antibody was found by Dr. S. Blix during studies on fibrinolysis. Its properties are described in another paper (Blix, 1961), and only a few data will be given here.

The patient R.K., a 58-year-old male, had a 5-year history of peripheral arterial insufficiency in both legs. Bilateral femoral-popliteal by-pass operations had been performed and were followed by secondary thrombosis with purulent ulcerations. These were treated locally with Varidase* eight times during the first 6 months of 1960 , and the antibody was demonstrated in November, 1960.

The present experiments were performed with serum samples obtained on different occasions in December, 1960, and January, 1961, and the antibody activity decreased slowly during this period. After chromatography on DEAE-cellulose (kindly performed by Dr. T. Reinskou), it was demonstrated by Dr. Blix that antibody activity was present in the fractions containing $7 \mathrm{~S} \gamma$ globulin. The patient was of type $\operatorname{Gm}(\mathbf{a}+\mathbf{b}+\mathbf{x}+)$. The serum titre was less than $1: 5$ in the Waaler-Rose test and the F.II latex particle test was negative.

\section{Tests for Rheumatoid Factor Activities}

Waaler-Rose Test.-This was made with human Group O Rh-negative red cells (Podliachouk, Eyquem, and Jacqueline, 1958), using the corresponding amboceptor from rabbits (commercial preparation, Institut Pasteur, Paris, France). The sensitizing amboceptor was used in one-quarter of the minimum agglutinating dose.

F.II Latex†-Particle Test.-This was performed according to Winblad (1960, and personal communication) with the following slight modifications: the suspension was stabilized with human albumin, and $0.15 \mathrm{M}$

* Varidase was the commercial preparation of Lederle, New York, N.Y., Lots No. 2201-108A and 2200-982A.

$+A k r y l$ plast particles (Latex) were kindly provided by AB Bofors, Nobelkrut, Bofors, Sweden. 
Sigma buffer $\mathrm{pH} 8.2$ was used. To $0.5 \mathrm{ml}$. serum dilution was added $0.5 \mathrm{ml}$. suspension of $\gamma$-globulincoated particles; the results were read macroscopically without centrifugation after sedimentation overnight at $37^{\circ} \mathrm{C}$.

Agglutination Tests with Red Cells Coated with Incomplete Anti-D.-These were made on slides as previously described (Harboe, 1959, 1960a). Rheumatoid sera containing anti-Gm(a) and anti-Gm(x) (Grubb, 1961a) were selected from the panel of sera used for $\mathrm{Gm}$-typing in this laboratory. Anti-D R.A. was used to coat red cells for determination of $\mathrm{Gm}(\mathrm{a})$ and $\mathrm{Gm}(\mathrm{x})$ types. Titres of anti-Gm(a) and anti-Gm(x) are given as the titres of sera known to contain these substances, when investigated with red cells coated with anti-D R.A. Anti-D S.V. was used for $\mathrm{Gm}(\mathrm{b})$ typing.

Red cells coated with anti-D Mu. and $\mathrm{Ri}$. are known to be agglutinated by nearly all rheumatoid sera showing positive Waaler-Rose and F.II latex-particle tests. Since these anti-D sera may be used diagnostically for the demonstration of rheumatoid factor activity, they are referred to as "diagnostic anti-D" in this paper. The antibodies are described in more detail elsewhere (Harboe, 1960b).

\begin{abstract}
Absorption Procedure.-One $\mathrm{ml}$. serum from the patient R.K. was incubated with $1 \mathrm{ml}$. of a solution of Varidase containing 10,000 units $/ \mathrm{ml}$. for $1 \mathrm{hr}$ at $37^{\circ} \mathrm{C}$. and $20 \mathrm{hrs}$ at $4^{\circ} \mathrm{C}$. Preliminary experiments indicated that these concentrations corresponded to the equivalence point of the precipitation curve. The precipitate was isolated by centrifugation for $30 \mathrm{~min}$. at $1,800 \mathrm{G}$, and washed three times in $10 \mathrm{ml}$. chilled saline. The washed precipitate (containing about $0.12 \mathrm{mg}$. nitrogen as determined by micro-Kjeldahl analysis) was used to absorb $2 \mathrm{ml}$. rheumatoid serum diluted 1 : 5 for $24 \mathrm{hrs}$ at $4^{\circ} \mathrm{C}$. The absorption was performed in sealed tubes during continuous slow movement to secure optimal contact between precipitate and serum. After absorption, the precipitate was removed by centrifugation and the supernatant transferred to a second tube for repeated absorption. The procedure was repeated for a different number of times, as indicated in the text. After the final absorption, the supernatant was tested for rheumatoid factor activities as indicated. For control, other portions of the rheumatoid sera diluted $1: 5$ were treated in exactly the same way, except that no precipitate was added. In most sera, a spontaneous precipitate formed within a few days and was removed during centrifugation. For additional control, a third tube of each diluted rheumatoid serum was frozen down $\left(-25^{\circ}\right.$ C.) at the beginning of the absorption procedure. The tubes were thawed at the end of the absorption procedure and tested simultaneously with the other materials. Spontaneous precipitates are known to contain rheumatoid factor (Christian, 1959), but there was no significant difference in activity between the frozen samples and the samples which were kept at $4^{\circ} \mathrm{C}$.
\end{abstract}

Quantitation of Precipitated Protein.*-To $0.75 \mathrm{ml} \stackrel{\oplus}{\stackrel{\oplus}{C}}$ serum R.K. was added $0.75 \mathrm{ml}$. Varidase containing 20,000 units $/ \mathrm{ml}$. This concentration of approximatel上. two times equivalence was chosen on the basis of datá? from Edelman, Kunkel, and Franklin (1958). The mixture was incubated for $1 \mathrm{hr}$ at $37^{\circ} \mathrm{C}$. before the addition of $0.75 \mathrm{Ul}$. rheumatoid serum A.H. or norma? sera showing negative Waaler-Rose and F.II latex흔. particle tests for control. After additional incubationf for $20 \mathrm{hrs}$ at $4^{\circ} \mathrm{C}$., the precipitates were spun down b centrifugation for $60 \mathrm{~min}$. at $1,800 \mathrm{G}$ at $4^{\circ} \mathrm{C}$. The supernatants were carefully removed and the precipitates washed twice in chilled saline. Finally, the precipitates were dissolved in $4 \mathrm{ml}$. 30 per cent. urea in $0.2 \mathrm{~N} \mathrm{NaOH}$ and the optical density was determined at $280 \mathrm{~m} \mu$ in as Beckman spectrophotometer, model DU-G2400.

\section{Experiments and Results}

Serological Activities before and after Absorption. The Figure (opposite) shows the results of absorptiorg experiments on a rheumatoid serum $(198 / \mathrm{LW})$ con= taining anti-Gm(a). After one absorption, antiø Gm(a) activity could no longer be demonstrated, nop were cells coated with "diagnostic" anti-D Ri. agglu㝋 tinated. The titres in the Waaler-Rose and F.IS latex-particle tests were also reduced, but to a less. degree.

The Figure also shows that another rheumatiid serum (270/AA), which also contained anti-Gm(a) gave similar results.

Serum S.V. contained anti-Gm(x) with a titre of $1: 640$. After one absorption with the immun precipitate, no anti-Gm(x) activity could be demon $\mathbb{B}$ strated.

Two rheumatoid sera with fairly strong sero logical reactions, which did not agglutinate red cells coated with anti-D R.A., were then investie gated. The serum titre was determined after fous times absorption with the immune precipitate in the Waaler-Rose test and F.II latex-particle test, and against red cells coated with "diagnostic" anti- $\vec{P}$. $\mathrm{Mu}$. and Ri., and compared with the unabsorbe $\$$ control.

Table I (opposite) shows that there was a marked reduction in all serological activities by the absorp tion procedure.

Quantitative Studies.-The results of one experiment are shown in Table II (opposite). It may be seen thap the amount of precipitated protein was greater wheriv

\footnotetext{
- Protein Preparations.-Pooled human $\gamma$-globulin was the com mercial preparation of AB Kabi, Stockholm, Sweden, Batch No.+ 70318. Human albumin was the commercial preparation of $\mathbf{A} \dot{B}$ Kabi, Batch No. 67103.
} 
SERUM 198/LW



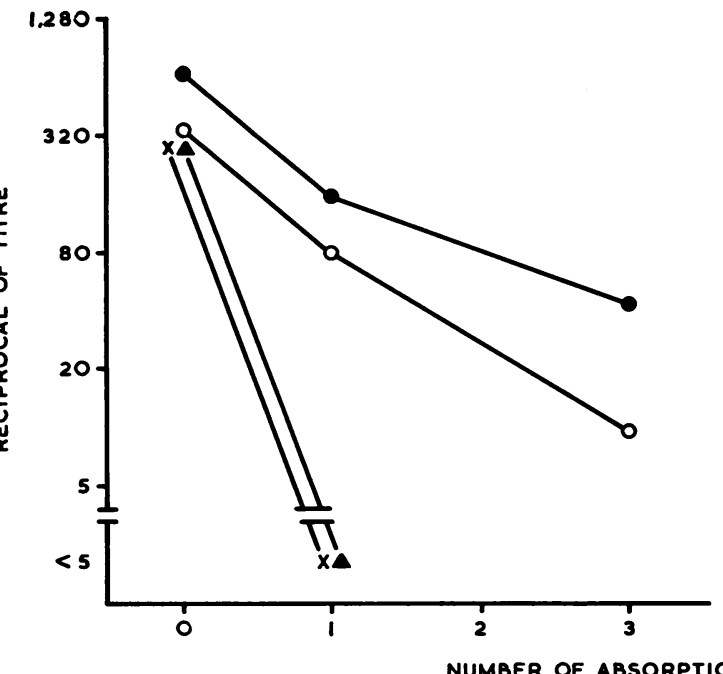

VARIDASE/HUMAN ANTIBOOY

Figure.-Absorption of rheumatoid serum 198/LW and 270/AA containing anti-Gm(a) with human specific precipitate.

TABLE I

ABSORPTION OF RHEUMATOID SERA WITH HUMAN SPECIFIC PRECIPITATE

Reciprocals of titres in each different test before and after four times absorption are given

\begin{tabular}{|c|c|c|c|c|c|c|c|c|c|}
\hline & & \multirow{2}{*}{\multicolumn{2}{|c|}{ Waaler-Rose }} & \multirow{2}{*}{\multicolumn{2}{|c|}{ F.II-Latex Particle }} & \multicolumn{4}{|c|}{ "Diagnostic" Anti-D Sera } \\
\hline \multicolumn{2}{|c|}{ Test } & & & & & \multicolumn{2}{|c|}{ Anti-D Mu. } & \multicolumn{2}{|c|}{ Anti-D Ri. } \\
\hline & & Before & After & Before & After & Before & After & Before & After \\
\hline \multirow{2}{*}{ Serum } & A.H. & 320 & 5 & 1,280 & $<5$ & 640 & $<5$ & 320 & $<5$ \\
\hline & O.H. & 320 & 20 & 2,560 & 20 & 320 & $<5$ & 320 & $<5$ \\
\hline
\end{tabular}

TABLE II

QUANTITATION OF PRECIPITATED PROTEIN

For technique of investigation, see text

\begin{tabular}{|c|c|c|c|c|}
\hline \multicolumn{4}{|c|}{ Reagents Incubated } & \multirow{2}{*}{ 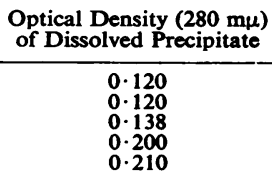 } \\
\hline & $\begin{array}{l}\text { Varidase } \\
\text { Varidase } \\
\text { Varidase } \\
\text { Varidase } \\
\text { Varidase }\end{array}$ & $\begin{array}{l}\text { Serum R.K. } \\
\text { Serum R.K. } \\
\text { Serum R.K. } \\
\text { Serum R.K. } \\
\text { Serum R.K. }\end{array}$ & $\begin{array}{l}\text { Saline } \\
\text { Normal Serum } 1 \\
\text { Normal Serum } 2 \\
\text { Rheumatoid Serum A.H. } \\
\text { Rheumatoid Serum A.H. }\end{array}$ & \\
\hline Controls & $\begin{array}{l}\text { Varidase } \\
\text { Saline } \\
\text { Saline } \\
\text { Saline } \\
\text { Saline } \\
\text { Varidase } \\
\text { Saline }\end{array}$ & $\begin{array}{l}\text { Saline } \\
\text { Serum R.K. } \\
\text { Saline } \\
\text { Saline } \\
\text { Saline } \\
\text { Saline } \\
\text { Serum R.K. }\end{array}$ & $\begin{array}{l}\text { Saline } \\
\text { Saline } \\
\text { Rheumatoid Serum A.H. } \\
\text { Normal Serum 1 } \\
\text { Normal Serum 2 } \\
\text { Rheumatoid Serum A.H. } \\
\text { Rheumatoid Serum A.H. }\end{array}$ & $\begin{array}{l}0 \\
0 \\
0 \cdot 010 \\
0 \\
0 \\
0 \\
0\end{array}$ \\
\hline
\end{tabular}


the immune precipitate was incubated with rheumatoid serum A.H. than after incubation with control sera showing negative tests for rheumatoid factor or saline. These findings were reproduced on three occasions. The experiment was made with only one rheumatoid serum (A.H.) because, as purified rheumatoid factor was not available, the tests had to be carried out with neat rheumatoid serum. Under these conditions, spontaneous precipitation (Christian, 1959) often makes interpretation difficult or impossible. Serum A.H. was selected because it was the only one, in a series of rheumatoid sera with fairly strong serological reactions, which gave only a trace of spontaneous precipitate after dilution $1: 5$ in saline and several days' storage at $4^{\circ} \mathrm{C}$. Relevant controls are included in the Table.

\section{Controls}

(1) Varidase is a purified preparation of the streptococcal enzymes streptokinase and streptodornase. Streptokinase activates the fibrinolytic system of human plasma and serum resulting in formation of plasmin (fibrinolysin) which is a proteolytic enzyme. In the organism, the activity of plasmin is directed primarily towards fibrin and, to some extent, fibrinogen. In addition, it may digest other proteins (Sherry, Fletcher, and Alkjaersig, 1959), possibly including the macroglobulins responsible for the activity in the present serological tests.

Four rheumatoid sera were incubated with Varidase under conditions optimal for plasmin formation (Blix, 1961). No reduction of serological activity was observed in the sera when compared with similar incubation with saline for control.

(2) Serum R.K. was of type Gm(a+). During the absorption procedure, $\operatorname{Gm}(\mathrm{a}+) \gamma$-globulin might therefore loosen from the immune precipitate in amounts sufficient to inhibit anti-Gm(a). After absorption of serum 198/LW (Figure), the following experiments were made to study this possibility:

To demonstrate the presence of $\mathrm{Gm}(\mathrm{a}+) \gamma$-globulin, we used anti-Gm(a) Kouba and red cells coated with anti-D R.A. In this system, Gm(a+) normal serum showed full inhibition of agglutination in dilutions up to $1: 1,280$, whereas $\mathrm{Gm}(\mathrm{a}-)$ normal serum did not inhibit in dilution $1: 5$. After three times absorption of serum 198/LW with the immune precipitate, dilution $1: 5$ had a definite inhibiting ability towards serum Kouba. At dilution $1: 10$, no inhibition was observed. The unabsorbed control of serum 198/LW did not inhibit in dilution $1: 5$ or higher-the latter experiment was performed after heating of diluted serum 198/LW to abolish its agglutinating ability (Grubb and Laurelf 1956; Harboe, 1960a). The results of the experiments are summarized in Table III.

\section{TABLE III}

ATTEMPT TO DEMONSTRATE Gm(a +) GAMMA-GLOBULF LOOSENED FROM SPECIFIC PRECIPITATE DURING ABSORPTION

Reagents: Anti-Gm(a) Kouba $1: 8$, red cells coated with anti-D R.A. Degree of agglutination recorded from +++ to - (cf. Harboe, 1960a)

\begin{tabular}{|c|c|c|c|c|}
\hline \multirow{3}{*}{$\begin{array}{c}\text { Dilution } \\
\text { of } \\
\text { Test } \\
\text { Material }\end{array}$} & \multicolumn{4}{|c|}{ Test Material } \\
\hline & \multicolumn{2}{|c|}{$198 / \mathrm{LW}$} & \multirow{2}{*}{$\frac{\mathrm{Gm}(\mathrm{a}-)}{\text { Control }}$} & \multirow{2}{*}{$\frac{G m(a+) \vec{\omega}}{\text { Control } \frac{\mathscr{\omega}}{2}}$} \\
\hline & $\begin{array}{c}\text { Before } \\
\text { Absorption* }\end{array}$ & $\begin{array}{c}\text { After } \\
\text { Absorption }\end{array}$ & & \\
\hline $\begin{array}{ll}1 & : 5 \\
1 & : 10 \\
1 & : 20 \\
1 & : 40 \\
1 & : 80 \\
1 & : 160 \\
1 & : 320 \\
1 & : 640 \\
1 & \vdots 1280 \\
1 & : 2560 \\
1 & : 5120\end{array}$ & $\begin{array}{l}++++ \\
++++ \\
++++ \\
++++ \\
++++ \\
++++ \\
++++ \\
++++ \\
++++ \\
++++ \\
++++\end{array}$ & $\begin{array}{c}t \\
+++ \\
++++ \\
++++ \\
++++ \\
++++ \\
++++ \\
++++ \\
++++ \\
++++ \\
++++\end{array}$ & 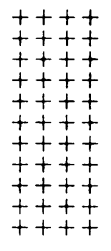 & 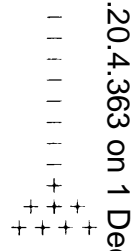 \\
\hline
\end{tabular}

* Serum 198/LW diluted $1: 5$ and heated at $65^{\circ} \mathrm{C}$. for 10 fin before testing (Grubb and Laurell, 1956; Harboe, 1960a).

After absorption of serum 270/AA (Figure), simgig experiments were made with virtually identical findings It was concluded that a minimal amount of $\mathrm{Gm}(\mathrm{a}+\overparen{O}$ $\gamma$-globulin loosened from the immune precipitate undew the experimental conditions. The amount was too smadi to abolish the anti-Gm(a) activity of the serum which was absorbed.

(3) Absorption of rheumatoid sera with immune precipitates consisting of various antigens and the corresponding rabbit antibodies may abolish seros logical activity in the Waaler-Rose test leaving the latex-fixation titres virtually unchanged. Corcos (1960) found that this was the case when humay albumin or purified $7 \mathrm{~S}$ human $\gamma$-globulin was use as antigen in the immune precipitate. He also found that immune precipitates containing aggre? gated human $\gamma$-globulin removed the activity its both serological tests, as does absorption with. aggregated human $\gamma$-globulin alone. An important source of error in the present experiments might therefore be that the antigen itself, Varidase, might react with the rheumatoid factor. Inhibition experios ments were made to clarify this point:

Four rheumatoid sera were diluted until they contained ten agglutinating doses in the different tests, and seriaf two-fold dilutions of a Varidase solution originalls containing 10,000 units $/ \mathrm{ml}$. were added in order to test for inhibiting capacity. In the Waaler-Rose test, $n \vec{\Theta}$ 
significant inhibition was found. In the F.II latexparticle test, slight inhibition was observed in the first two tubes. Anti-Gm(a) Kouba and 198/LW were not inhibited by Varidase (these experiments were performed using red cells coated with anti-D G63, see below). Whether the agglutination of red cells coated with anti-D Ri. was inhibited by Varidase, could not be tested because it was found that the preparation agglutinated such cells.

Rh-positive red cells were coated with ten different strong incomplete anti-D sera and tested for agglutination by serial dilutions of a Varidase solution originally containing 10,000 units $/ \mathrm{ml}$. Red cells coated with one anti-D serum (G63) were only weakly agglutinated in a narrow concentration range of Varidase, while cells coated with any of the other anti-D antibodies were strongly agglutinated. A "prozone phenomenon" was observed with six of the anti-D antibodies; no agglutination was observed by the highest concentrations of Varidase, whereas lower concentrations of the preparation showed strong agglutinating ability. The basic nature of this agglutination is unknown. It is probably not of enzymic nature, as the activity was somewhat stronger at $4^{\circ} \mathrm{C}$. than at $37^{\circ} \mathrm{C}$. The agglutination was inhibited by low concentrations of both human albumin and $\gamma$-globulin.

It was concluded from these experiments that Varidase itself did not inhibit the rheumatoid factor to a significant degree and, accordingly, that such inhibition could not explain the findings of the absorption experiments.

\section{Discussion}

The rheumatoid factor is able to react with $\gamma$ globulin of diverse origins. Theoretically of great importance is whether it can react with human $\gamma$-globulin in vivo, and whether this reaction is of any pathophysiological consequence for the individual.

Experiments in this laboratory (Harboe, 1961) indicate that anti-Gm(a) is a separate component of the complex of closely related macroglobulins usually designated as rheumatoid factors. Anti$\mathrm{Gm}(\mathrm{a})$ and the other specific agglutinating substances of the $\mathrm{Gm}$ system are inhibited by native human 7S $\gamma$-globulin (Grubb, 1961b). Similar reactions are directly observed in experiments using red cells coated with selected incomplete anti-D antibodies, where prozones often occur in agglutination tests. It has been demonstrated that these prozones are frequently caused by the simultaneous presence of an agglutinating substance and its specific inhibitor in individual rheumatoid sera (Swahn and Grubb, 1958; Harboe, 1960a). Additional evidence for a reaction between rheumatoid factor and human $\gamma$-globulin in vivo is the presence of the $22 \mathrm{~S}$ complex in some rheumatoid sera. Rheumatoid factor is composed of 19S $\gamma$-globulins which often exist in the circulation bound to 7S $\gamma$ globulin, and this complex has a sedimentation coefficient of 22S (Franklin, Kunkel, MüllerEberhard, and Holman, 1957).

At the beginning of the experiments described in this paper, the behaviour of rheumatoid factor with immune precipitates containing antibody of human origin was scarcely known. The only data available were those on rheumatoid serum S.H., which was absorbed by Vaughan (1956) with a precipitate consisting of diphtheria toxin and human antitoxin. There was no reduction in activity after absorption as judged by the Waaler-Rose test. The reasons for the discrepancy between Vaughan's findings and ours are probably that we did repeated absorptions, whereas his serum appears to have been absorbed only once, and that the other tests (demonstration of anti-Gm(a) and agglutination of red cells coated with "diagnostic" anti-D) are more sensitive than the Waaler-Rose test (Figure). The present findings showed that different components of the rheumatoid factor were adsorbed on to the specific precipitate containing human antibody.

After completing the present investigations, we learned of the important paper of Aho, Kirpilä, Wager, and Virkkunen (1961). They immunized two patients with rheumatoid arthritis, who had strongly positive serological reactions, with diphtheria toxoid, and both patients developed strong precipitating antibodies. It was found that rheumatoid factor was adsorbed to, and could be eluted from, the precipitates, which consisted of diphtheria toxoid and the patients' own antitoxins. Identical findings were made by three different tests for rheumatoid factor activity: the Waaler-Rose test, the F.II latex-particle test, and an agglutination test with red cells coated with anti-D $\mathbf{R i}$.

Studies on the Gm system have shown that components of the rheumatoid factor may react with the individual's own native $\gamma$-globulin (Swahn and Grubb, 1958; Harboe, 1960a). The present experiments show that the rheumatoid factor is adsorbed on to immune precipitate containing antibody of human origin. The experiments of Aho, Kirpilä, Wager, and Virkkunen (1961) further demonstrate that immune complexes containing precipitating antibody from rheumatoid arthritis patients react with their own rheumatoid factor. It remains to be demonstrated whether these phenomena observed in vitro may indicate autoimmune mechanisms in rheumatoid arthritis.

\section{Summary}

The behaviour of rheumatoid factor was studied with an immune precipitate consisting of "Varidase" and a human 7S $\gamma$-globulin antibody. Different 
components of rheumatoid factor [as defined by the Waaler-Rose test, F.II latex-particle test, agglutination tests with red cells coated with "diagnostic" anti-D, and demonstration of anti-Gm(a) and anti$\mathrm{Gm}(\mathrm{x})$ ] were all absorbed on to this immune precipitate.

The author is highly indebted to Prof. R. Grubb and to Drs. H. Fudenberg, O. Hartmann, P. Herzog, P. Linnet-Jepsen, and J. H. Vaughan for the provision of valuable reagents.

\section{REFERENCES}

Aho, K., Kirpilä, J., Wager, O., and Virkkunen, M. (1961). Ann. Med. exp. Fenn., 39, 66.

Blix, S. (1961). Acta med. scand., 170, 201.

Christian, C. L. (1959). Arthr. and Rheum., 2, 289.

Corcos, J. (1960). Ibid., 3, 439.

Edelman, G. M., Kunkel, H. G., and Franklin, E. C. (1958). J. exp. Med., 108, 105.

Foz, A., and Batalla, E. (1956). In "Contemporary Rheumatology": Proc. 3rd European Rheumatology Congress, The Hague, 1955, ed. J. Goslings and H. van Swaay, pp. 166-9. Elsevier, Amsterdam.

Franklin, E. C., Kunkel, H. G., Müller-Eberhard, H. J., and Holman, H. R. (1957). Ann. rheum. Dis., $16,315$.

Grubb, R. (1956). Acta path. microbiol. scand., 39, 195.

- (1961a). Nature (Lond.), 189, 845.

- (1961b). Arthr. and Rheum., 4, 195.

—_ and Laurell, A.-B. (1956). Acta path. microbiol. scand., 39, 390.

Harboe, M. (1959). Ibid., 47, 199.

-(1960a). Ibid., 50, 89.

— (1960). Ibid., 50, 383. International Congress of Rheumatology, Rome, 1961.

Mellors, R. C., Nowoslawski, A., Korngold, L., and Sengson, B. L. (1961). Arthr. and Rheum., 4, 120.
Podliachouk, L., Eyquem, A., and Jacqueline, F. (1958). Ann. Inst. Pasteur, 94, 659.

Rose, H. M., Ragan, C., Pearce, E., and Lipman, M. O.믕. (1948). Proc. Soc. exp. Biol. (N.Y.), 68, 1.

Sherry, S., Fletcher, A. P., and Alkjaersig, N. (1959). $\overrightarrow{\vec{F}}$ Physiol. Rev., 39, 343.

Swahn, B., and Grubb, R. (1958). Acta path. microbiol. scand., 42, 173.

Vaughan, J. H. (1956). J. Immunol., 77, 181.

$\longrightarrow$, Ellis, P. J., and Marshall, H. (1958). Ibid.,$\stackrel{\mathbb{Q}}{\varrho}$ 81, 261.

Waller, M. V., and Vaughan, J. H. (1956). Proc. Soc. exp. Biol. (N.Y.), 92, 198.

Winblad, S. (1960). Acta path. microbiol. scand., $49,499$.

Waaler, E. (1940). Ibid., 17, 172.

Interactions du facteur rhumatismal avec un immun précipité contenant des anticorps d'origine humaine

RÉSUMÉ

On étudia le comportement du facteur rhumatisma $\omega$ avec un immun-précipité consistant de "Varidase" et? d'un anticorps humain, la globuline gamma 7S. De différents composants du facteur rhumatismal-définis par la réaction de Waaler-Rose, la réaction F.II d'agglu-D tination de particules de latex, des réactions d'agglutina tion des globules rouges enduites d'anti-D "diagnostique'? et mise en évidence d'anti-Gm(a) et anti-Gm(x)-furen tous absorbés dans ce immun-précipité.

Interacciones del factor reumatoide con un inmuneprecipitado conteniendo anticuerpos de origen humpro-

\section{SUMARIO}

Se estudió el comportamiento del factor reumatoide con un inmune-precipitado conteniendo "Varidase" un anticuerpo humano, la globulina gamma 7S. Dife rentes compuestos del factor reumatoide-definidos poß la reacción de Waaler-Rose, la reacción F.II de aglu $\underset{\Rightarrow}{\vec{F}}$ tinación de partículas de latex, reacciones de aglutinacióng de eritrocitos cubiertos de anti-D diagnóstico y com? probación de anti-Gm(a) y anti-Gm(x)-fueron todos absortos en este inmune-precipitado. 